\title{
Analysis on the Objectives and Curriculum Characteristics of Outdoor Training Institutions in Europe and America
}

\author{
Zijian Liu, Han Yang*
}

China University of Geosciences, Wuhan, China

*Corresponding author. Email: 18602706407@163.com

\begin{abstract}
In order to promote the healthy development of outdoor training institutions in China, this paper analyzes 18 training institutions in 6 countries, including the United States, the United Kingdom, Australia, New Zealand, Germany and Canada, and summarizes the characteristics of their goals and courses, so as to provide reference and reference for outdoor training industry.
\end{abstract}

Keywords: Outdoor, Training Institutions, Objective, Curriculum.

\section{OVERVIEW OF OUTDOOR TRAINING INSTITUTIONS IN EUROPEAN AND AMERICAN COUNTRIES}

Europe and America have developed economy, high level of modernization, and the leisure sports industry such as outdoor sports is booming. In order to meet the needs of industry development, outdoor vocational training started earlier in European and American countries, and there are many outdoor training institutions. Focus on outdoor industry employees to carry out technical specifications of the level of training and qualification recognition. Training programs are based on specific outdoor activities and related content, such as mountain guides, climbing instructors, etc.The training duration ranges from one day to one year. Practical courses occupy the main body of the training, the training place is generally in the actual working environment, and the evaluation is mainly to obtain the professional qualification of the specific project.

By summarizing the information of 18 outdoor training institutions, the training topics are divided into comprehensive categories and single categories. Key words of organization name show the main business of each organization, comprehensive organization named by "mountain guide association" more, mainly carry out mountain guide, hiking, rock climbing, skiing, mountain biking, canoeing and other courses; Individual institutions mainly carry out rock climbing and skiing two events related courses.
Table 1. 18 Outdoor training institutions

\begin{tabular}{|c|c|}
\hline Category & Name of institution \\
\hline \multirow{14}{*}{$\underset{\mathrm{d}}{\text { Integrate }}$} & $\begin{array}{c}\text { International Federation Of Mountain Guides } \\
\text { Associations(IFMGA) }\end{array}$ \\
\hline & $\begin{array}{c}\text { National outdoor leadership school } \\
\text { (NOLS) }\end{array}$ \\
\hline & American Camp Association (ACA) \\
\hline & $\begin{array}{c}\text { New Zealand Mountain Guides } \\
\text { Association(NZMGA) }\end{array}$ \\
\hline & Outdoor Education New Zealand(OENZ) \\
\hline & Association of Mountaineering Instructors(AMI) \\
\hline & $\begin{array}{l}\text { Verband der Deutschen Berg- und } \\
\text { Skiführere.V.(VDBS) }\end{array}$ \\
\hline & The outward bound trust \\
\hline & Active UK Skills (SKILLSACTIVE UK) \\
\hline & Active Outdoor Pursuits \\
\hline & American Mountain Guides Association(AMGA) \\
\hline & British Mountain Guide(BMG) \\
\hline & Association of Canadian Mountain Guides(ACMG) \\
\hline & British Mountaineering Council(BMC) \\
\hline \multirow{4}{*}{$\begin{array}{l}\text { Single } \\
\text { item }\end{array}$} & $\begin{array}{l}\text { Professional Association of Climbing Instructors } \\
\text { (PACI) }\end{array}$ \\
\hline & $\begin{array}{c}\text { The Australian Professional Snowsport } \\
\text { Instructors(APSI) }\end{array}$ \\
\hline & All Tracks Academy \\
\hline & $\begin{array}{l}\text { New Zealand Snowsports Instructors Alliance } \\
\text { (NZSIA) }\end{array}$ \\
\hline
\end{tabular}


Table 2. Examples of objectives of outdoor training institutions

\begin{tabular}{|c|c|}
\hline $\begin{array}{c}\text { Name of } \\
\text { institution }\end{array}$ & \multicolumn{1}{|c|}{ Training objectives } \\
\hline $\begin{array}{c}\text { National outdoor } \\
\text { leadership school } \\
\text { (NOLS) }\end{array}$ & $\begin{array}{l}\text { Training techniques and mountaineering } \\
\text { skills to enrich the experience of guiding } \\
\text { on high altitudes or accompanying } \\
\text { expeditions. }\end{array}$ \\
\hline $\begin{array}{c}\text { New Zealand } \\
\text { Mountain Guides } \\
\text { Association } \\
\text { (NZMGA) }\end{array}$ & $\begin{array}{l}\text { Provide standards and competency } \\
\text { requirements for mountain guides and } \\
\text { standardize the quality of guidance } \\
\text { through training and certification } \\
\text { processes. }\end{array}$ \\
\hline $\begin{array}{c}\text { Association of } \\
\text { Mountaineering } \\
\text { Instructors } \\
\text { (AMI) }\end{array}$ & $\begin{array}{l}\text { Motivate, assist and develop walking, } \\
\text { climbing and mountaineering through the } \\
\text { provision of nationally and } \\
\text { internationally recognised skills training } \\
\text { and leadership qualifications. }\end{array}$ \\
2. OBJECTIVES ANALYSIS OF OUTDOOR
\end{tabular}

The change in the demand of outdoor leisure industry in Europe and the United States has changed the objective of outdoor training from focusing on "technical skills" to "experiential methods" with more complex skills. Through the analysis of the objectives of 18 outdoor training institutions, the following characteristics are summarized:

\subsection{It Still Takes Technical Skills as the Core and has Detailed Classification of Skill Targets}

Although the outdoor industry places more emphasis on the comprehensive competencies and "soft skills" of its practitioners, as outdoor leadership, theory and management courses are all built on the initial skills learned. In addition, because the vocational qualification examination is often based on knowledge and skills, therefore, the training objective is particularly prominent technical skills, skills standards are formulated in very detailed. The NOLS, for example, aims to "become the primary source and teacher of wilderness skills and leadership for people and the environment." The PACI aims for the skills of climbing instructors in terms of equipment skills, rope skills, motor skills, safety skills and protection skills.

\subsection{Standardize Service, Dedicated to Promote the Development of Outdoor Standardization}

After years of development, European and American countries have formulated the technical grade standards for different outdoor sports projects, and the assessment system is relatively perfect, but the organizational form is relatively free. For example, the Australian National Board of Education has developed the canoe standard;
The national coaching program sets standards for crosscountry skiing, but there are also many sports that do not have clear standards at the national level, such as bush walking and rappelling. Due to the lack of regulation, the service quality of employees is uneven, and the accidents caused by it also cause people's concern. Therefore, many institutions are committed to promoting the standardization construction, standardizing outdoor guidance behavior and guaranteeing the service quality. For example, SkillsActive UK works with expert working groups to develop National Occupational Standards (NOS), which set out the knowledge and skills required for the profession and serve as the basis for industry qualifications across the UK.

\subsection{Obtain Professional Qualification Certification to Adapt to the New Requirements of the Industry}

National vocational qualification certification is the basic requirement of the country to engage in a certain occupation necessary knowledge, technology and ability, is an important part of the final evaluation of many vocational training, is also the "ticket" of outdoor professionals on the job, so that students to obtain vocational qualification certification is the common goal of training courses. At the same time, professional qualifications are constantly changing and updated to reflect the high standards and new demands placed on professionals, such as the IFMGA 's guidelines to keep the industry growing and relevant in a changing world'. At the same time, there are many vocational qualification certification systems in European and American countries, and each institution usually establishes its own certification system, carries out training and assessment under the guidance of national standards. At the same time, a variety of industry awards are issued to encourage learners to actively acquire vocational abilities.

\subsection{Accumulate Practical Experience, Transform to Ability and Consciousness}

Faced with the constantly changing natural environment and customer needs, practitioners are required to improve their abilities and qualities to adapt to the new environment and new conditions. For example, meticulous itinerary arrangement, appropriate route selection, skilled technical operation and timely risk prediction are all indispensable to the experience accumulated in practice. Gaining some outdoor practice experience is a prerequisite for some advanced qualifications. For example, German mountain and ski guide training requires at least 3 years of experience in mixed terrain and travel reporting party is eligible to enroll; The MTA's International Mountain Leader Qualification training requires learners to have a record of 20 high quality International Mountain Day experiences in the UK or overseas. 


\subsection{Restore the Real Working Environment and Improve the Practical Application Ability}

The working environment of outdoor practitioners is often very complex, and the skills learned in different environments will produce large deviations in the application. In order to ensure that learners play a good skill level in a specific environment, the training objectives of training institutions focus on the authenticity of occupational scenarios. Students need to not only acquire technical skills, but also learn how to apply knowledge and skills in the real workplace. For example, the PACI has two categories of rope skills: ground operation and aerial operation, to simulate the possible working environment to the greatest extent. OENZ alpine guide training objectives specifically emphasize the task of independent leader from the mentor, to create a learning and practice environment close to the real working environment for learners.

\subsection{Deliver Professional Values and Permeate the Concept of Sustainable Development}

These organizations emphasize the values of the outdoors, risk, responsibility, and education, and emphasize professionalism, a sense of mission, and professional loyalty. Groups such as the AMI in the UK and Ireland spread the idea of safe enjoyment of climbing mountains. The NOLS is committed to creating a welcoming, fair and inclusive environment for its students, communicating wilderness values and environmental ethics, and instilling sustainable development into its practices.

\section{CURRICULUM ANALYSIS OF OUTDOOR TRAINING INSTITUTIONS IN EUROPE AND AMERICA}

\subsection{The Curriculum is Diverse with Emphasis on Safety and Risk Management}

Training courses offered by outdoor institutions include comprehensive courses with relatively free forms of activities and complex contents, such as mountain guide and risk service, as well as courses for sports with a higher degree of standardization, such as rock climbing, skiing and canoeing. In addition, there are courses on safety and risk, environmental protection, medicine, education and other aspects. Guarantees the life safety of customers under the premise of providing customer service conditions, all institutions put safety and risk management in the first place, but also in the form of courses for specialized training. Such specialized courses as Avalanche First Aid (AIARE), Wilderness Medicine and Risk Services (NOL), and Rope Rescue (PACI) highlight the importance of safety and risk management in the training of outdoor professionals in European and American countries.

\subsection{Practical Courses Account for a Relatively High, Technical Skills First Emphasis on Safety}

Outdoor work is closely related to outdoor technical skills. Proficient mastery of outdoor technical skills is the premise for outdoor workers to carry out work, ensure safety and successfully complete activities. Among the specific courses under each course, theoretical courses generally account for a small proportion, while practical courses account for more than $80 \%$. For example, out of the 94 days of IFMGA mountain guides' total training days, the length of practical courses reached 84 days. In practical courses, the course content is mainly technical skills, and the priority is to learn safety skills. OENZ climbing course begins with the teaching of safety skills such as equipment inspection and route safety assessment.

\subsection{The Curriculum System is Perfect, Taking into Account the Needs of Multi-level Customers}

In order to meet the diverse needs of learners with different foundation for training content, the outdoor training curriculum system in European and American countries has been gradually improved. Courses are usually divided into two or more levels in order to cater for students with uneven fundamentals and to connect closely between the levels. For example, APSI divides ski courses into four levels, corresponding to beginner, course teacher, intermediate and private course instructor and professional instructor four levels. Students can choose their own training courses according to their own experience and qualifications.

\subsection{Rational Use of Social Resources, Give Full Play to Their Own Advantages}

Some institutions actively collaborate with other institutions or universities. It is beneficial to improve the training quality and save the cost by using the superior social resources to supplement the courses of the institution. At the same time through the form of cooperation with universities to expand the training channels to strengthen the relationship with universities. For example, ACMG outsources Alpine Wilderness First Aid courses to 14 designated organizations; NOLS further expand its influence by offering outdoor courses and professional courses to colleges and universities, as well as mutual recognition of college credits.

\subsection{Pay Attention to the Cultivation of Self- awareness, and Create a Fair and Inclusive Atmosphere}

Most of the institutions recruit students from the whole society, and there are differences in nationality, race, religious belief, age, gender and so on. Each 
institution strives to create a fair and inclusive learning atmosphere. Training is also available for persons with disabilities who meet the registration requirements. Both APSI and NZSIA offer training courses in adaptive skiing for persons with disabilities. In addition, it pays attention to the cultivation of students' self-awareness, which is an important quality for outdoor employees. The centrality of students is emphasized in the training. Coaches help students to know themselves and form selfawareness, and help learners to adapt to their future career roles through role exchange, which is conducive to the acquisition of vocational ability. In addition, compared with colleges and universities, training institutions pay more attention to maintaining long-term cooperative relations with learners. Some learners often sign a contract with training institutions for teaching or other work in the industry after obtaining the qualification.

\subsection{The Course Content is Based on Vocational Qualification Standards to Promote International Mutual Recognition of National Qualifications}

The important goal of vocational training is to strengthen the vocational ability and obtain the vocational qualification certification. Therefore, the curriculum is set closely around the vocational qualification standards. Many national associations are committed to unifying the construction of international outdoor professional qualification standards. For example, the main goal of the IFMGA is to "regulate the mountain guide industry globally", "determine authoritative professional qualification standards" and "promote the mutual recognition of IFMGA qualifications". Some institutions have also established independent certification systems based on international or national standards, which generally need to meet national or international standards to ensure the standardization and recognition of their qualifications. For example, the ACMG has established a system of certification that allows individual project instructors to be certified within their own organization, as well as through mutual recognition of a series of qualifications that eventually lead to certification by the International Association of Mountain Guides.

\section{CONCLUSIONS AND IMPLICATIONS}

Outdoor training institutions in European and American countries take outdoor skills as the main training goal, and are committed to promoting the standardized development of outdoor industry. They attach great importance to professional qualifications and practical experience, and guide students to establish professional values and cultivate the concept of sustainable development. The training curriculum system is perfect, based on practical courses, highlighting the importance of safety and risk management, taking into account multi-level needs, and making full use of social resources to supplement the curriculum.

Establish a perfect training target system, detailed technical standards, pay attention to the training of basic professional skills, professional practice ability; Pay attention to the cultivation of professional values, guide the formation of students' professional spirit, sustainable development and environmental concepts; Pay attention to the standardization of outdoor industry and the construction of professional qualification certification system, standardize the service behavior of the industry; At the same time of giving full play to their own advantages, rational use of social resources, actively cooperate with other institutions or universities to improve the quality of training. The training of outdoor professionals in China can draw on the experience of the mature system of European and American countries to build a bridge between training institutions and vocational qualification certification.

\section{REFERENCES}

[1] Grubb, Norton W, Lazerson, et al. Vocationalism in Higher Education: The Triumph of the Education Gospel.Journal of Higher Education, 2005.

[2] Manfield L, Pearse J. A Way For A National Outdoor Leader Course. Journal of Outdoor and Environmental Education, 1998, 3(1):58-65.

[3] Deborah Sugerman. Outdoor Leadership Education: The Past, Present and Future. college curriculum, 1999:8.

[4] Mann K. Rethinking professional pathways for the Australian outdoor industry/profession. Journal of Outdoor \& Environmental Education, 2003, 7(1):49.

[5] John, Luckner. Effective Skills Instruction in Outdoor Adventure Education. Journal of Physical Education, Recreation \& Dance, 1994.

[6] Dickson T J, Herbert Z. Outward bound Australia: reflecting on integrating vocational education into the workplace. Journal of Outdoor \& Environmental Education, 2005, 9.

[7] Priest S. Preparing Effective Outdoor Pursuit Leaders. 1987. 